
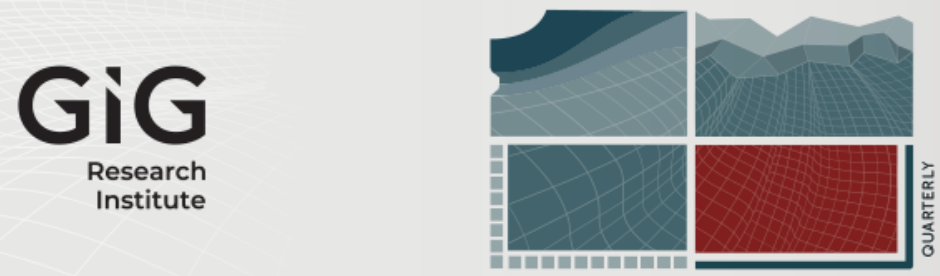

JOURNAL

OF

SUSTAINABLE

MINING

\title{
Growth of invasive plant species communities as a substantial issue in post-mining land development
}

Author(s) ORCID Identifier:

Paweł Olszewski (iD 0000-0003-3020-7670

Follow this and additional works at: https://jsm.gig.eu/journal-of-sustainable-mining

Part of the Explosives Engineering Commons, Oil, Gas, and Energy Commons, and the Sustainability Commons

\section{Recommended Citation}

Olszewski, Paweł (2021) "Growth of invasive plant species communities as a substantial issue in postmining land development," Journal of Sustainable Mining: Vol. 20 : Iss. 3 , Article 5.

Available at: https://doi.org/10.46873/2300-3960.1321

This Research Article is brought to you for free and open access by Journal of Sustainable Mining. It has been accepted for inclusion in Journal of Sustainable Mining by an authorized editor of Journal of Sustainable Mining. 


\title{
Growth of invasive plant species communities as a substantial issue in post- mining land development
}

\begin{abstract}
This article concerns the issue of the appearance and growth of invasive plant species in land degraded by hard coal mining and the repercussions of this process, particularly in the context of land reclamation. These species, such as Canadian goldenrod or Japanese knotweed, which nearly always form extensive and monocultural patches of vegetation, contribute to the displacement of both native species and those introduced as part of biological restoration. In 2015, the Central Mining Institute in Katowice prepared a land development concept for a part of the area of the former KWK Paryż mine in Dąbrowa Górnicza (Upper Silesian Industrial Region - Poland), based on its resources and potential, encompassing the "Jadwiga" dump and its vicinity. The presented actions scenarios did not fully factor in the issue related to the growth and control of invasive plant species. Studies of the growth of invasive species communities, conducted from 2015 to 2019 with the use of UAV (unmanned aerial vehicles), revealed the significant propagation of the Japanese knotweed Polygonetum cuspidati (Moor 1958) Th. Müller et Görs 1969 ex Görs 1974 association as well as the Canadian goldenrod Solidago canadensis community. Their elimination increases the cost of the reclamation by $18 \%$.
\end{abstract}

\section{Keywords}

post-mining areas, reclamation costs, invasive plant species, Canadian goldenrod community, Japanese knotweed association, unmanned aerial vehicles

\section{Creative Commons License}

(c) (i)

This work is licensed under a Creative Commons Attribution 4.0 License. 


\title{
Growth of invasive plant species communities as a substantial issue in post-mining land development
}

\author{
Paweł Olszewski
}

Central Mining Institute, Department of Environmental Monitoring, Plac Gwarków, 40-166, Katowice, Poland

\begin{abstract}
This article concerns the issue of the appearance and growth of invasive plant species in land degraded by hard coal mining as well as the repercussions of this process, particularly in the context of land reclamation. These species, such as e.g. Canadian goldenrod or Japanese knotweed, which nearly always form extensive and monocultural patches of vegetation, contribute to the displacement of both native species and those introduced as part of biological restoration.

In 2015, the Central Mining Institute in Katowice prepared a land development concept for a part of the area of the former KWK Paryż mine in Dąbrowa Górnicza (Upper Silesian Industrial Region - Poland), based on its resources and potential, encompassing the "Jadwiga" dump and its vicinity. The presented actions scenarios did not fully factor in the issue related to the growth and control of invasive plant species. Studies of the growth of invasive species communities, conducted from 2015 to 2019 with the use of UAV (unmanned aerial vehicles), revealed the significant propagation of the Japanese knotweed Polygonetum cuspidati (Moor 1958) Th. Müller et Görs 1969 ex Görs 1974 association as well as the Canadian goldenrod Solidago canadensis community. Their elimination increases the cost of the reclamation by $18 \%$.
\end{abstract}

Keywords: post-mining areas, reclamation costs, invasive plant species, canadian goldenrod community, Japanese knotweed association, unmanned aerial vehicles

\section{Introduction}

$\mathrm{H}$ ard coal mining in the Dąbrowa Basin, a part of the Upper Silesian Industrial Region (GOP) since 1950, has been conducted since the end of the 18th century [1]. Many areas have undergone transformation as a result of the mining activity due to their physical, chemical and biological degradation. It is imperative to restore their regular economic, social and environmental functions as quickly as possible. Reclamation of land degraded by the mining industry depends primarily on the degree of the anthropogenic changes, the location of the site and the needs of the local administration or land owners. The projects and concepts for land development typically include the work that must be done, i.e. terrain formation, water drainage, soil purification, planting shrubs and trees. At the same time, the planned work should also factor in the natural qualities and potential that can almost always be exhibited by the degraded land. Examples may include the architectural, cultural and historical qualities of post-industrial sites, the extraordinary biodiversity of the spontaneously appearing flora or the reserves of raw material for recovery and use. The economic analysis of the planned work should encompass all the circumstances and factors that require financial outlays. An example of action that is very rarely included in the economic analysis is the elimination of invasive plant species that appear in the unused degraded land. These species displace native taxons, suppress planting planned as part of the biological restoration, and in extreme cases also constitute a direct hazard to human health and wellbeing. Some of them, i.e. traveller's joy Clematis vitalba L., thicket creeper Parthenocissus inserta (A.KERN.) or Jerusalem artichoke Helianthus tuberosus L., can be eliminated relatively easily, whereas should they be retained and properly controlled, they may perform decorative functions. Other species, i.e. Canadian horseweed Conyza canadensis L., annual fleabane Erigeron annuus (L.) or New York aster Aster novi-belgii L., are nearly guaranteed to appear in degraded and reclaimed land, and their 
elimination seems practically impossible. Furthermore, extensive communities and associations are particularly problematic, as they are characterised by significant durability, fast growth and resistance to control. Such formations include Canadian goldenrod communities and Japanese knotweed associations. Although the Canadian goldenrod community is characterised by high decorative qualities and provides valuable nectar flow during fluorescence, its negative influence consists primarily in the ease of its introduction into natural and anthropogenic biotopes as well as the creation of widespread monocultures and the displacement of species native or planted as part of biological restoration efforts. Eliminating the Canadian goldenrod communities may consist in repeated mowing during the year and the subsequent use of e.g. natural herbicides based on pelargonic acid, which do not linger in the soil and the water. The Japanese knotweed association, which can currently be found in many places in Poland and the rest of Europe, is particularly difficult and expensive to control. Socioeconomic consequences of controlling the plant in Great Britain were estimated at a level of 165,6 million pounds per year [2]. Eliminating the knotweed from the area of the London Summer Olympics cost 70 million pounds, whereas the costs of its elimination across the entire United Kingdom were estimated at a level of about 1.56 billion pounds [3]. Knotweeds (including Sakhalin and Bohemian knotweed) are particularly characterised by their extraordinary regenerative capabilities, clearly observable, for example, when the epigeal parts of the plants are damaged (e.g. by mowing), which stimulates the generation of new sprouts. Knotweeds propagate primarily through growth and rhizome fragmentation [4]. Knotweed rhizomes can be situated at a depth of $3 \mathrm{~m}$ in the subsoil and may propagate even to a distance of $7 \mathrm{~m}$ away from the parent plant [5]. Eliminating the knotweed only by clearing is ineffective in a medium and long-term perspective [6]. An effective knotweed control method is to mow the epigeal parts of the plant and to replace the soil, as performed in cases of strongly contaminated land. This method of elimination becomes very problematic in cases of extensive areas occupied by the plant, and it generates very high costs related to the performance of action involving heavy machinery and the removal of the subsoil containing the rhizomes, which must subsequently be buried at a great depth. Spraying is an effective knotweed control method as well, though it exhibits significant limitations. The most commonly utilised herbicides based on glyphosate can have a negative influence on surface and ground water. Their effects are not selective and thus they also eliminate coexisting plants, which often rules out this method for use in valuable or protected areas. Issues such as the correlation between the use of glyphosate and the incidence of cancer in humans were revealed as well [7]. Despite the above problems, among all the methods used for the elimination of the knotweed, the application of glyphosate at the appropriate phenological growth stages of the plant is the most effective [8].

Unmanned aerial vehicles (UAV) are very useful for the assessment of areas occupied by selected invasive plant species. Coloured orthophotomaps depict the ranges of individual formations, while flights repeated regularly during fluorescence become a helpful tool for monitoring the growth of individual associations and communities, and for planning action related to their elimination $[9,10]$.

This article presents the technical and economic issues pertaining to action intended for the elimination of invasive plant species, which is viewed as a key element of the complex planning of miningdegraded land reclamation. A vegetation inventory taken in 2015 and the monitoring of the growth of the Canadian goldenrod community and the Japanese knotweed association performed in the years 2016-2019 in the degraded area of the "Jadwiga" dump and the terrain adjacent to the former KWK Paryż mine in Dąbrowa Górnicza present a new perspective regarding the additional costs related to the reclamation of this area.

\section{Materials and methods}

\subsection{Location and characteristics of the studied area}

The area encompassed by the invasive plant species and community studies is located in the south-western part of Dąbrowa Górnicza (Poland), in the vicinity of Filtrowa street. It constitutes a part of the former hard coal mine Paryż (Fig. 1). The central part contains a separate area dedicated to economic activity.

The post-industrial waste dump "Jadwiga", established in the $1960 \mathrm{~s}$, occupies its major part. It is formed of made ground, most of which constitutes carbonaceous shale, burnt shale, clay slate, sandstone debris, sinter, slag and fine coal. It is of an irregular shape with numerous, occasionally very steep slopes. From the south, the immediate vicinity of the dump is an extensive and level flat area. Its western part includes minor piles of coal slurry, most likely originating from a filled sedimentation tank. The dump, raised to a level of $386.3 \mathrm{~m}$ above sea level, is mostly covered with a young birch, false 
acacia and poplar community. No technical or biological restoration was ever attempted in the area of the dump and its vicinity - nearly all the vegetation is an effect of natural succession. Wild elderberry Sambucus nigra L. is the most prominent shrub. Gaps in stand density as well as open spaces are occupied by communities and associations of ruderal plants characteristic of post-industrial areas: Lolio-Polygonetum arenastri, Convolvulo arvensis - Agropyretum repentis, Calamagrostietum epigeji, Echio-Melilotetum and Artemisio-Tanacetetum vulgaris. Shaded and slightly waterlogged areas are typically occupied by the Urtico - Aegopodium podagrariae and CalystegioEupatorietum associations [10]. Vast formations of invasive species that span extensive areas include: the Japanese knotweed Polygonetum cuspidati (Moor 1958) Th. Müller et Görs 1969 ex Görs 1974 association, the Canadian goldenrod Solidago canadensis

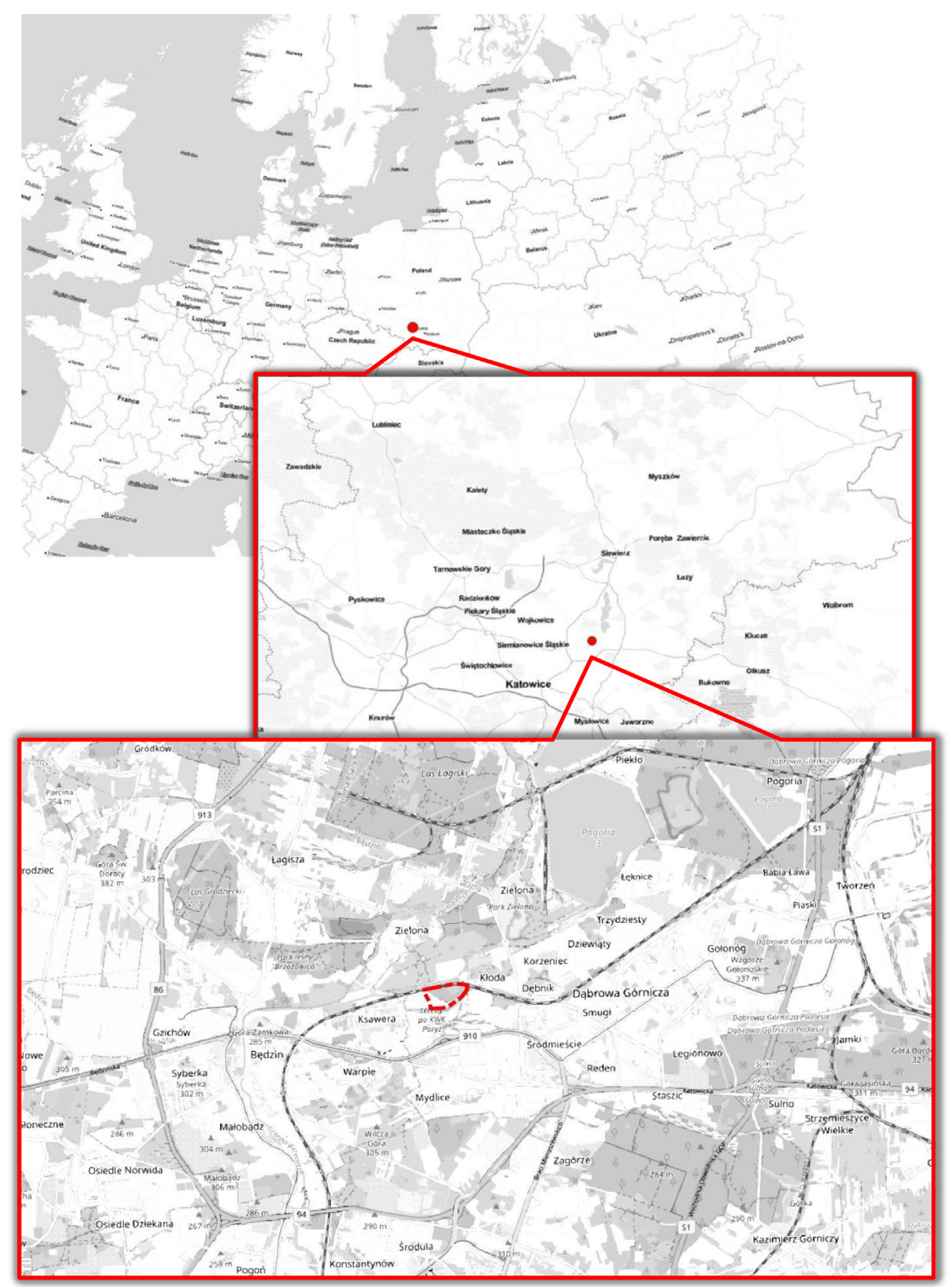

Fig. 1. Location of the site encompassed by the reclamation concept and the invasive plant species inventory. 


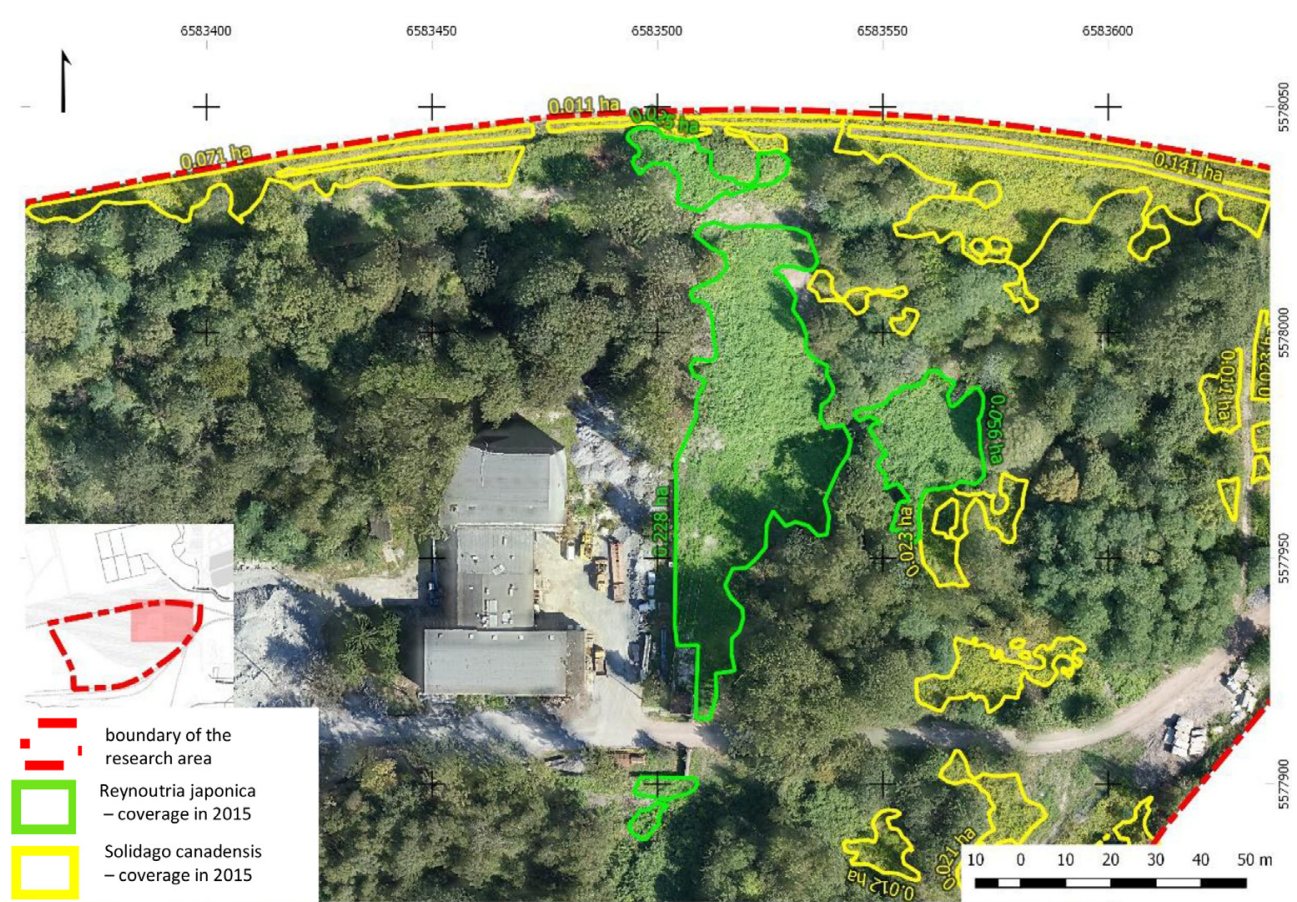

Fig. 2. Combined orthophotomap fragment - north-eastern part of the studied location with marked patches of invasive species and their areas. Yellow outline - Canadian goldenrod community; green outline - Japanese knotweed association. State for the year 2015. Source: authors' analysis [10].

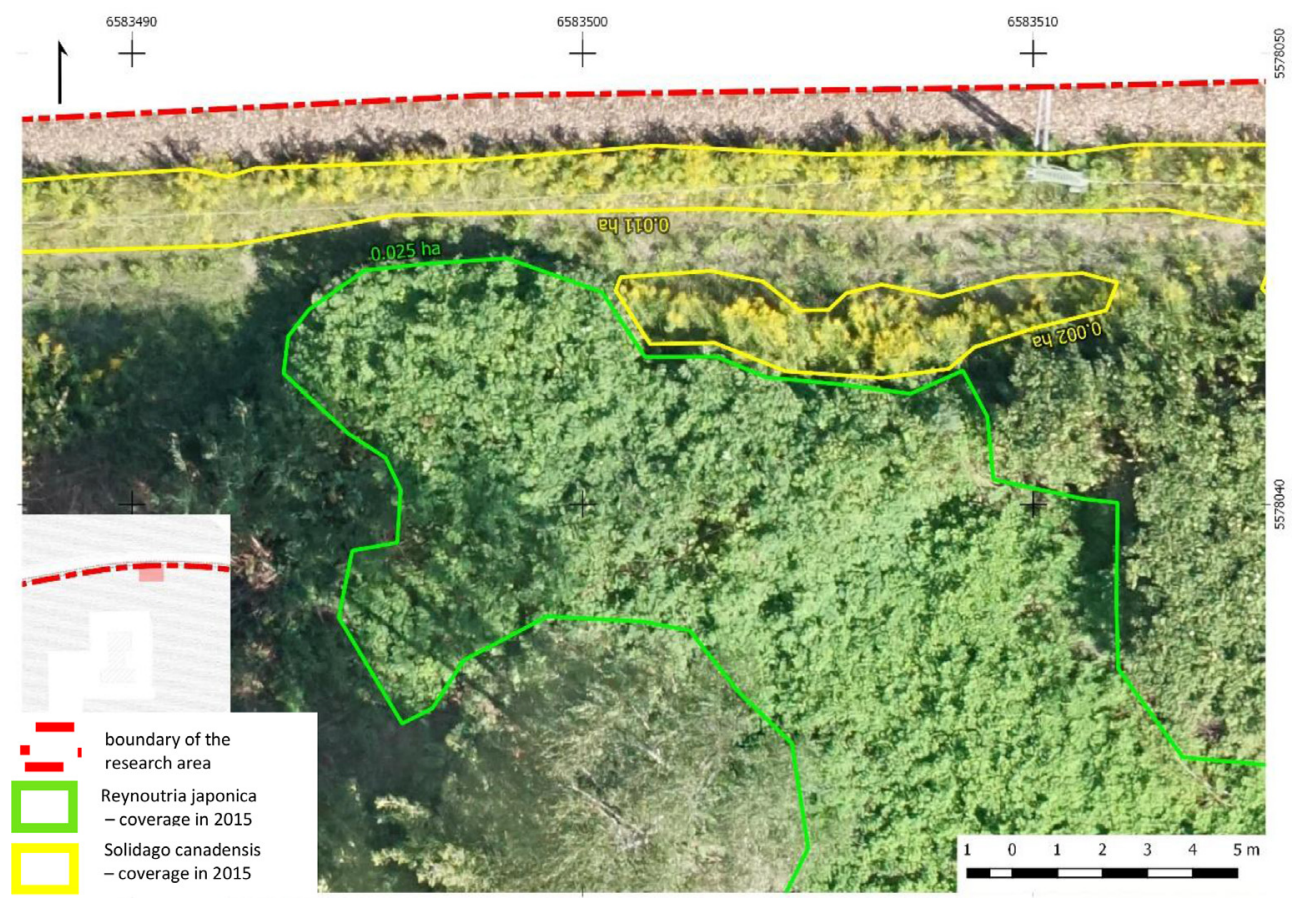

Fig. 3. Enlarged fragment of the orthophotomap in Fig. 2. Yellow outline - Canadian goldenrod community; green outline - Japanese knotweed association. The red line denotes the north border of the studied area. State for the year 2015. Source: authors' analysis [10]. 
community and the false acacia Robinia pseudoacacia community.

Observations made during numerous surveys indicate the presence of deer, hedgehogs, hares, sedentary birds and birds of prey (common kestrel, sparrowhawk and buzzard) as well as at least two species of frog. However, such fauna is not an exception in these types of post-industrial areas.

Despite its strongly anthropogenic character, the area has high natural value. The dense vegetation offers a habitat for numerous species of fauna and flora. At the same time, it functions as a wildlife corridor and ecological junction with adjacent areas.

\subsection{Conducted studies and inventories}

In 2015, the Central Mining Institute prepared a variant-based concept for the development/reclamation of the "Jadwiga" dump and its vicinity together with an economic analysis for the Dabrowa Górnicza Municipality. All the variants factored in the presence of great quantities of diverse post-industrial waste in the area of the "Jadwiga" dump and its vicinity, which could be recovered and subsequently used. The presence of dense vegetation in the form of trees and shrubs, which present natural potential and could, in the case of the trees, constitute a source of wood, was important for the prepared variants. Other important factors included the favourable location within the city centre, good transport potential, clear ownership status and a defined position in the Area Development Plan of the Dąbrowa Górnicza Municipality.

The quantity and quality of the waste collected in the area was assessed based on existing studies provided by the Municipality. Furthermore, the area encompassed by the concept was subjected to thermal activity testing during the summer, which provided no indications of thermal activity in either the old, elevated part of the dump or in its other sections.

The tall vegetation inventory was taken in a manner enabling the assessment of wood resources while simultaneously determining the costs related to the logging. The inventory indicated the presence of 4482 trees in the studied area, mostly false acacias $(30 \%)$, poplars $(30 \%)$, birches $(20 \%)$ and willows $(10 \%)$. Other species, i.e. oak, maple, linden, chestnut, pine, elm, ash and bird cherry, constituted about $9.5 \%$. The great majority of the trees could be exempted from logging fees, based on art. 86 of the Polish Environmental Protection Law of 16th April, 2004, as amended. The logging fees for the remaining trees were estimated at a level of about 1.2 million EUR. The value of the obtainable wood was based on a wood quality inspection and was estimated to be worth 29 thousand EUR.

Using archival geological studies and updated geodesic measurements, a spatial model of the "Jadwiga" dump was constructed, encompassing both its above-surface and subsurface parts. Useful strata were identified, including those potentially containing coal and aggregates. Feasible technologies for recovery were specified as well.

The first flights over the studied area using unmanned aerial vehicles were also performed in 2015 . Images taken by the UAV enabled the preparation of an orthophotomap of the area, which clearly displayed the Canadian goldenrod community and the Japanese knotweed association.

\section{Results and discussion}

\subsection{Reclamation variants}

Analysing the authors' own studies, the spatial model, the available reports and the conducted field surveys resulted in the preparation of a variantbased concept for the reclamation of the "Jadwiga" dump and its vicinity, together with a recommendation of the most favourable variant.

Five variants were prepared.

Variant " 0 " assumed that the dump and its vicinity would not be altered, in order to retain the already established post-industrial ecosystem. The site would have a natural, educational and scientific function.

Variant "I" assumed that the cone of the dump would be dismantled and the terrain would be levelled to $267 \mathrm{~m}$ above sea level. It could be accomplished in three ways. Option "A" involved transferring the waste to a specialist company for processing. In option "B", the waste would be sorted in situ and the obtained products (coal and aggregates) would be sold or used for the levelling. Option "C" assumed transporting all the unnecessary material for recovery outside the installation or transferring it to a stockyard.

Variant "II" assumed that the cone of the dump would be dismantled and the terrain would be levelled to $263 \mathrm{~m}$ above sea level. It could be accomplished in three ways, similarly to variant "I", where options "A" and "C" were identical as in variant "I". Option "B" assumed the recovery and use of the aggregates. Only the coal was to be sold.

Variant "III" assumed that the cone of the dump would be dismantled, while useful material would be extracted from the subsurface part of the dump, and finally the terrain would be levelled to $267 \mathrm{~m}$ above sea level. The variant involved waste sorting 
in situ, selling the obtained coal and using the remaining material for the levelling.

Variant "IV" assumed that the cone of the dump would be dismantled (like in variant "II"), while useful material would be extracted from the subsurface part of the dump, and finally the terrain would be levelled to $263 \mathrm{~m}$ above sea level. Processing would encompass material obtained from the dismantling of the dump cone above the level of $263 \mathrm{~m}$ as well as from excavations below the level of $263 \mathrm{~m}$ until the bottom of the useful strata. The final levelling to a height of $263 \mathrm{~m}$ above sea level would result in a lowering of the entire area relative to the railway embankments by the north side.

An economic analysis was performed for variants "I-IV", which included the costs of performing the groundwork and territorial development as well as the income from selling the obtained aggregates and coal, and selling the terrain to external investors.

The obtained results indicated that implementing any of the analysed variants was economically inefficient. This was due to the very high expenditures necessary to prepare and develop the terrain for the needs of the future investors. The financial outlays would not be compensated by the income obtained from selling the wood and the products acquired through the sorting of the materials deposited in the dump, even when including the potentially high income from selling the area to investors.

The negative outcome of the conducted variantbased economic efficiency analysis was primarily influenced by the low value of the materials deposited in the "Jadwiga" dump. The cost of their sorting exceeded the potential income from selling the obtained products (coal and aggregates) despite the proposed use of a modern and relatively inexpensive dry sorting method. This was primarily due to the low market price of coal and the low content of the coal itself in the material deposited in the "Jadwiga" dump.

At the same time, the prepared concept analysed the possibility of obtaining financial support for the individual variants in the form of European Union subsidies. The results of this analysis clearly indicated that variants "IC" and "IB" would become efficient at a subsidy level of $25 \%$ and $35 \%$ respectively. In the case of variant "IA", the project would become economically efficient assuming a subsidy of $85 \%$.

An element that generated significant costs in variants "I-IV" was the logging fee for the trees identified during the inventory of the studied area (1.2 million EUR). Avoiding this fee would guarantee the economic efficiency of variants "IA", "IIB",
"III" and "IV". Only variants "IIA" and "IIC" would remain economically inefficient.

\subsection{Inventory of invasive plant species and communities}

Post-industrial areas, including mining and metallurgical waste dumps, are characterised by high biodiversity. This is related to the mosaic character of their intertwining and diverse habitats as well as the terrain adjacent to them. The "ecological niches" that form here are places where many rare, or even protected species of fauna and flora can be found. They are also places that include numerous invasive plant species, which are almost always characterised by excellent adaptive capabilities in harsh conditions through e.g. the production of great quantities of seeds, the growth of subterranean organs (rhizomes) or their resistance to dry soil, pests and diseases. This leads to a displacement of native species and an impoverishment of the flora.

The presence of 10 invasive plant species was identified in the area of the "Jadwiga" dump and its vicinity. These included: box elder Acer negundo L., New York aster Aster novi-belgii L., annual fleabane E. annuus (L.), traveller's joy C. vitalba L., Canadian horseweed C. canadensis (L.), Jerusalem artichoke H. tuberosus L., thicket creeper Parthenocisus inserta (A. KERN), Japanese knotweed Reynoutria japonica Houtt., false acacia R. pseudoacacia L. and Canadian goldenrod S. canadensis L. [11-14]. Most of them could be found in small patches or individually in nearly the entire area.

Particular attention should be devoted to the presence of three vast, widespread formations of invasive species: the Canadian goldenrod community $-S$. canadensis, the Japanese knotweed association - P. cuspidati (Moor 1958) Th. Müller et Görs 1969 ex Görs 1974 and the false acacia community R. pseudoacacia.

The last of the aforementioned communities (R. pseudoacacia), according to the inventory taken for the purposes of the potential logging, was comprised of specimens located primarily on the elevated part of the dump, to a total of over 1300 trees. Only 13 of them exhibited a circumference of over $100 \mathrm{~cm}$ at a height of $130 \mathrm{~cm}$ - average age of over 72 years [15]. The thickest false acacia had a circumference of $122 \mathrm{~cm}$ at a height of $130 \mathrm{~cm}-$ average age of over 84 years [15]. The great majority (about $80 \%$ ) of the trees were specimens with trunk thicknesses of $20-50 \mathrm{~cm}$ (average age of 17-39 years). The false acacia patches comprising younger specimens were characterised by high density and 
were always accompanied by other species of deciduous trees, i.e. aspen and warty birch.

The Canadian goldenrod community was present in the form of dense or partially scattered patches in relatively flat areas exposed to solar radiation. The greatest area occupied by the community was found by the north side, adjacent to the railway tracks and footpaths. Minor and medium patches of the community were present in the entire studied location, often growing in areas that were not occupied by other perennials, shrubs and trees.

The Japanese knotweed association was present in the form of very dense patches, practically without other co-existing species, in places both strongly dry and slightly waterlogged located in an area of local depressions. It frequently occupied spaces between older trees and shrubs in the central and northern part of the studied area [10].

\subsubsection{Changes in invasive community surface areas}

Flights over the "Jadwiga" dump and its vicinity were started in the autumn of 2015. The surface of the studied area was 17.05 ha. The studies employed a remote-controlled aerial vehicle integrated with a Sony ILCE-6000 camera with a 24 Mpx matrix and a Sony SEL30-M35 $30 \mathrm{~mm} \mathrm{f} / 3.5$ lens. The flights were conducted at a height of $150 \mathrm{~m}$ and the adopted ground sample distance (GSD) was $2.0 \mathrm{~cm} / \mathrm{px}$. The obtained RGB images were used to prepare a coloured orthophotomap of the studied area.

Clearly visible areas occupied by Canadian goldenrod and Japanese knotweed were manually marked and their planimetry was measured. The flights were conducted during optimal goldenrod fluorescence. Selected patches were measured traditionally using a measuring tape for purposes of comparison and verification.

In 2015, the Canadian goldenrod community occupied a total area of 1.218 ha, which constituted $7.14 \%$ of the studied area. The Japanese knotweed association occupied $0.281 \mathrm{ha}$, which constituted $1.64 \%$ of the area. Selected fragments of the studied location orthophotomap are presented below, with marked and measured goldenrod and knotweed areas.

Flights over the studied area were also conducted from 2016 to 2019. Clear changes in the areas occupied by the communities in question were observed on the prepared orthophotomaps.

The growth of the Canadian goldenrod community in 2016 compared to the year 2015 was $17.56 \%$. The total area occupied by this species in 2016 was $1.43 \mathrm{ha}$. In subsequent years (2017-2019), its growth in the studied area was about $5 \%$ per year. In this period, the goldenrod exhibited a minor growth in the analysed patches, spreading into available gaps in co-existing communities in flat areas strongly exposed to solar radiation. The area occupied by the goldenrod in 2019 was about 1.6 ha.

Clear changes in the occupied area were also noted for the Japanese knotweed. In 2015, the patches of this association occupied a total area of 0.281 ha. In 2016, the area occupied by the knotweed patches was 0.254 ha (decrease by $9.47 \%$ ), which was a result of maintenance work carried out by the leaseholder/entity conducting business activities in the area of the former "Filtering station". The work encompassed levelling a fragment of the terrain at the east side of the fence by means of heavy machinery (Figs. 4 and 5), and levelling the ground and removing vegetation at the north side of the main building (Figs. 6 and 7).

Simultaneously, there had been a growth of the knotweed patches in other areas since 2016. The plant increased its range very dynamically in the groups that had been observed earlier. Analysing one of the smaller patches located in the east part of the studied area (Fig. 8) reveals its growth from $40 \mathrm{~m}^{2}$ (state for the year 2016) to $73 \mathrm{~m}^{2}$ in 2019 - an increase in surface area at a level of $82 \%$. It would appear that the key factor for the dynamic growth in this case was the free space around the patch. Its further growth will continue southward and most likely advance along the hard-surfaced footpath by the west side.

New, previously unidentified "hotspots" also appeared in places formerly occupied by herbaceous plants.

From 2016 to 2019, the Japanese knotweed association in the studied area grew by $4422 \mathrm{~m}^{2}$. As a result of the groundwork carried out in 2016 and the minor herbicide spraying in 2019, the area of the patches temporarily decreased by $484 \mathrm{~m}^{2}$. The estimated area occupied by the knotweed in 2019 (flights conducted in October) was 0.648 ha.

\subsubsection{Invasive species community growth repercussions and control efforts}

Each of the ultimately adopted reclamation variants for the "Jadwiga" dump and its vicinity first requires solving the issue of the spontaneous invasion of invasive plant species and their communities into the area in question.

The 2015 concept prepared by GIG did not include solutions for this process, as its scale was inadequately understood at the time. The first flights using UAV intended for the observation of invasive species communities were conducted in the autumn of that year. Information gained from the performed vegetation inventory primarily 


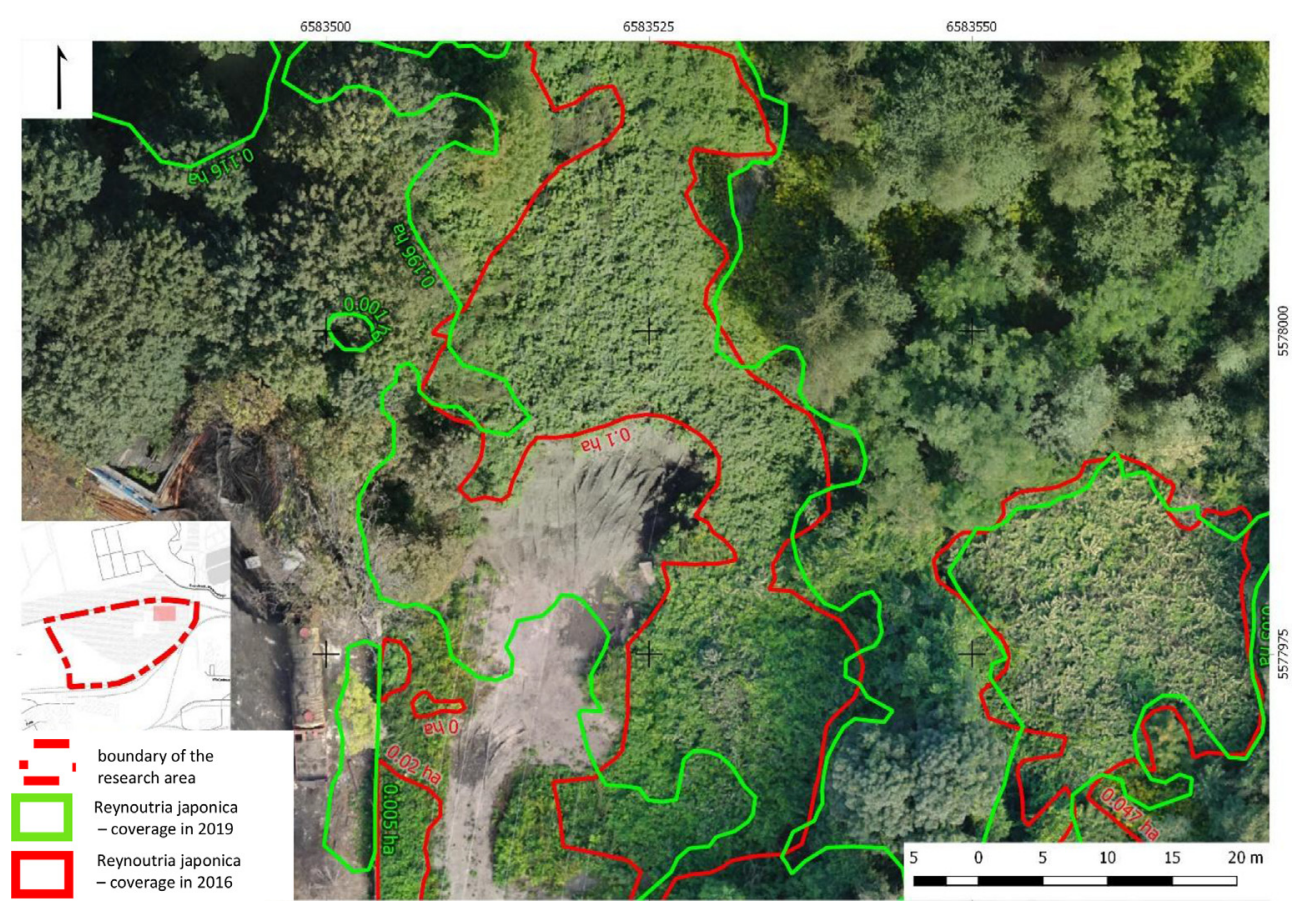

Fig. 4. Fragment of an orthophotomap from 2016. Groundwork in the area of the "Filtering station's" eastern fence. Visible removed part of the ground together with patches of the Japanese knotweed. The red line denotes the range of the patches in 2016, whereas the green line provides the range in 2019.

concerned the false acacia community, whose influence on the area and the reclamation variants was at the time considered in terms of logging costs as per art. 84, 85 and 86 of the Polish Environmental
Protection Law [16] and potential wood yields. Subsequent years of observation conducted from 2016 to 2019, focused on the growing patches of the Canadian goldenrod S. canadensis community and

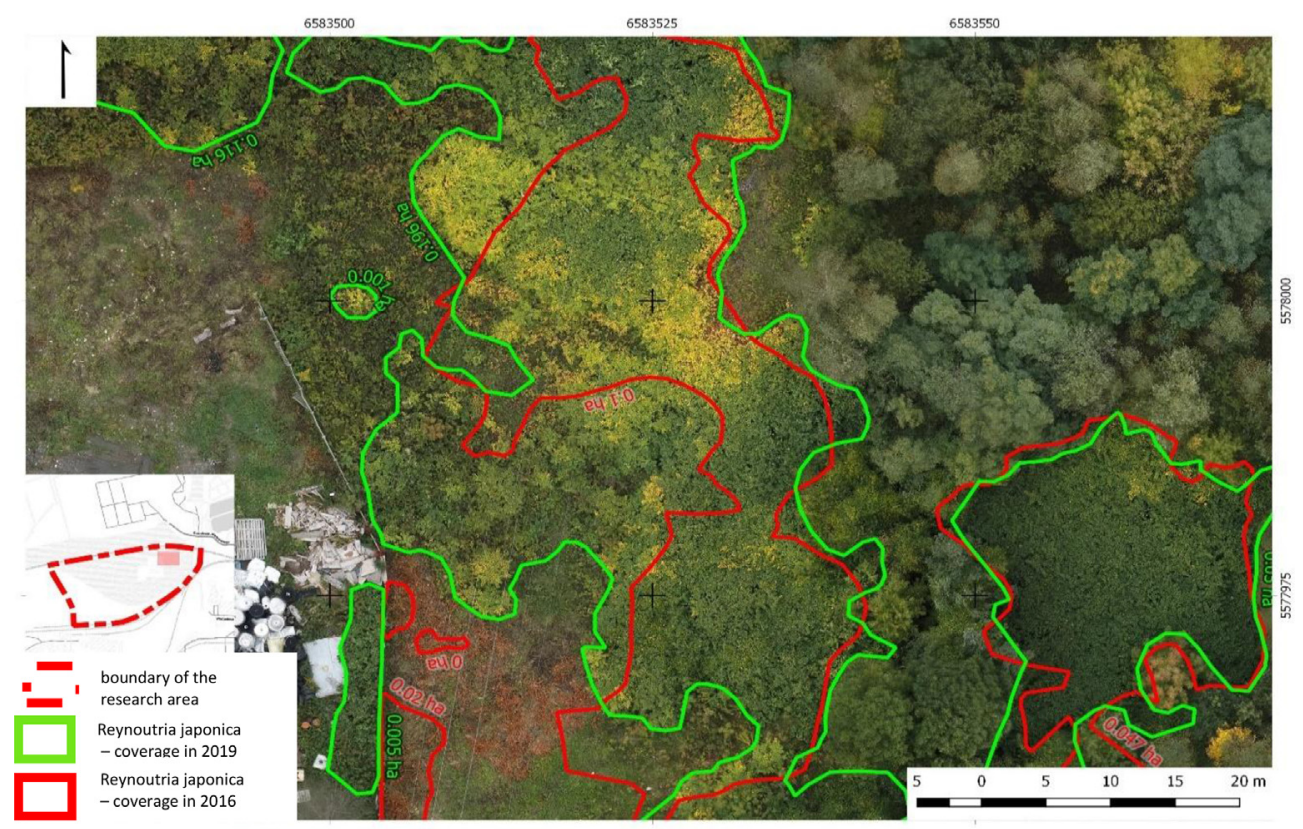

Fig. 5. Fragment of an orthophotomap from 2019. The groundwork carried out in 2016 "exposed" the subsoil containing knotweed rhizomes (see Fig. 4). Visible patch growth in the central part of the image. Herbicide spraying was applied to a part of the patch in $2019-$ visible light-brown, desiccated parts of the plants. 


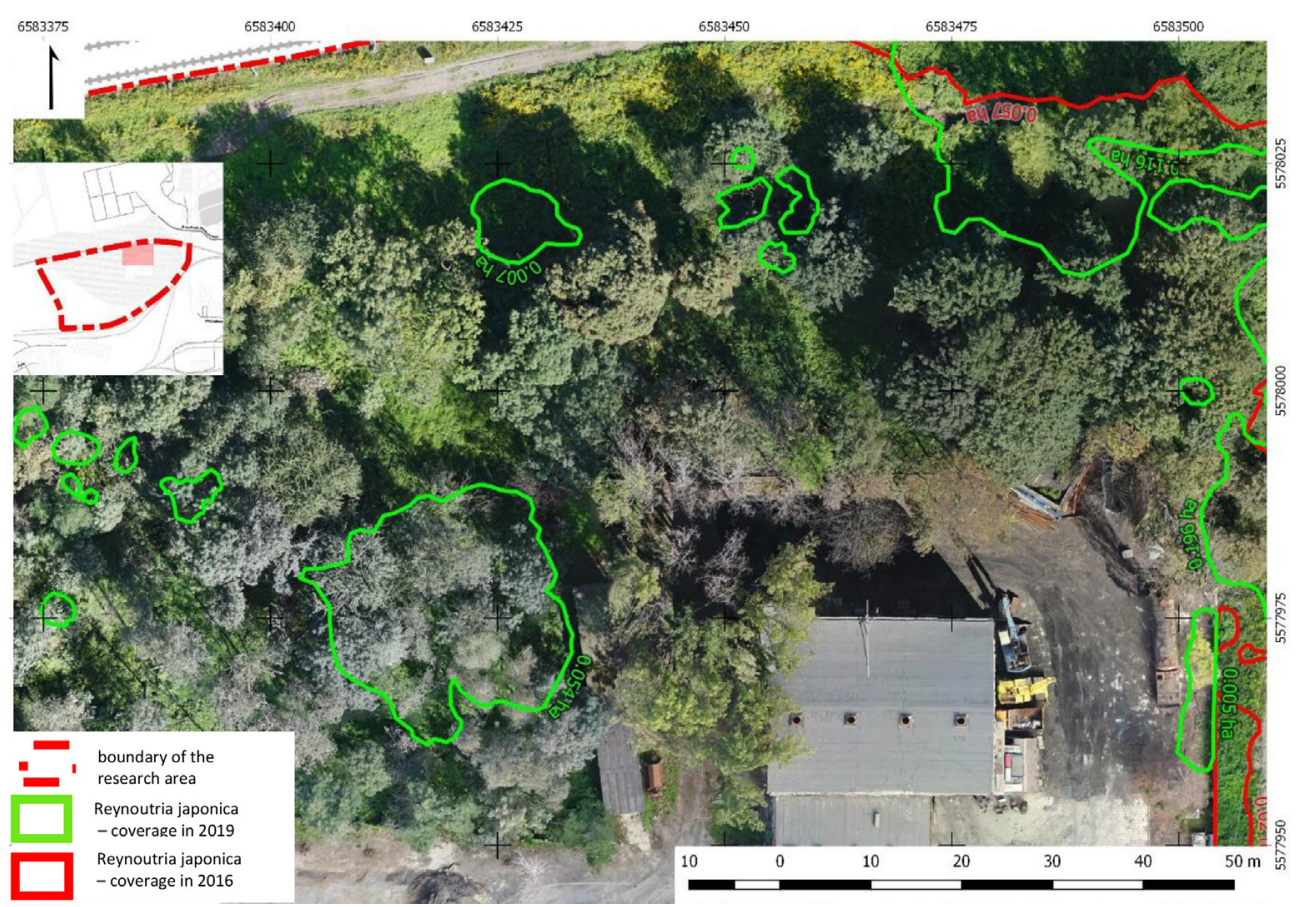

Fig. 6. Fragment of an orthophotomap from 2016. The trees, shrubs and perennials by the north side of the main "Filtration station" building were removed as part of the maintenance work.

the Japanese knotweed P. cuspidati (Moor 1958) Th. Müller et Görs 1969 ex Görs 1974 association, document the scale of the problem, while the measured surface areas of the patches make it possible to provide a new perspective regarding reclamation costs.

Determining the range of the false acacia community by means of UAV is difficult and may be burdened with a significant error. Though the locations occupied by false acacia are adequately visible in vertical images during optimal fluorescence (May, June), in many cases other trees, such as warty birch, aspen, sycamore and goat willow, also have a significant presence in the community. Additionally, determining the range of the community is nearly impossible as young specimens originating from self-seeding, which are found at its borders, blossom only after 8-15 years. For this reason, monitoring the community using orthophotomaps was disregarded, and the one-time elimination (logging) cost estimation was based on the vegetation inventory taken in 2015 .

The false acacia community, located primarily on the elevated part of the dump, consisted of over 1300 specimens, $80 \%$ of which constituted trees of an average age of 17-39 years. In all the reclamation variants, except for variant " 0 ", the dump was to be levelled, therefore no further maintenance and care procedures were planned following the actual logging. The logging fee estimated at the time for the false acacia trees that could not be exempted from it was about 69 thousand EUR. The costs related to the felling, skidding and fragmentation of all the trees of this species were estimated at a level of 5.4 thousand EUR. Since the circumferences of the trees did not undergo significant change over the course of the four years following the detailed inventory, the logging fees decreased only slightly (3.07 EUR per $\mathrm{cm}$ of false acacia circumference in 2015 to 2.66 EUR per $\mathrm{cm}$ of circumference in 2020), while the cost of man-hours for the forest work increased, therefore it was assumed that the false acacia removal costs would remain at a similar level in 2020 and would amount to about 74.5 thousand EUR. In the case of variant " 0 ", the false acacia community would need to be retained.

In 2019, the Canadian goldenrod community occupied an area of 1.6 ha (1.218 ha in 2015). Regardless of the adopted reclamation variant (except for variant "0"), the Canadian goldenrod community can be eliminated through two-time mowing with manual motor mowers e.g. in May and August or at the beginning of June and September prior to fluorescence. The procedure should be repeated in the next three or four years $[17,18]$. Spraying using a natural herbicide based on pelargonic acid, which does not linger in the soil and the water, can be performed about two weeks prior to the mowing [19]. The spraying after moving should be repeated in the subsequent years. The cost of these efforts, depending 


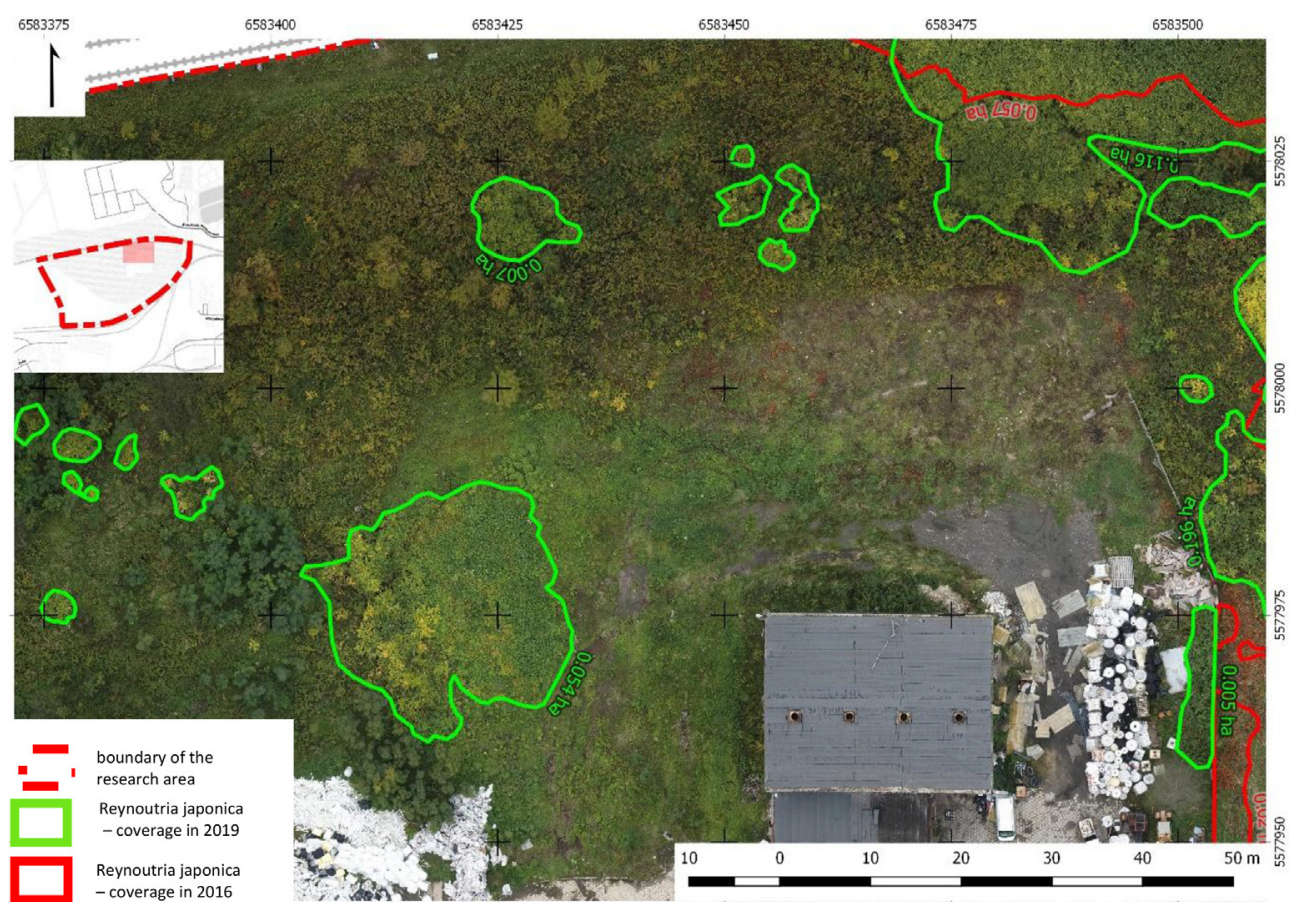

Fig. 7. Fragment of an orthophotomap from 2019. Exposed and levelled areas were colonised by the Japanese knotweed association. The green line denotes patches with a height of about $1.5 \mathrm{~m}$. Young sprouts from remaining and grown rhizomes were found in nearly the entire area.

on the shape and availability of the terrain as well as the utilised equipment, is estimated at a level of 2.2 thousand to 6.6 thousand EUR/ha, which at the adopted average spraying, mowing and groundwork cost of 4.4 thousand EUR/ha, the double performance of the action during the year and the surface area of about 1.6 ha yields a yearly cost of about 11.5 thousand EUR. The north-eastern area will prove difficult in

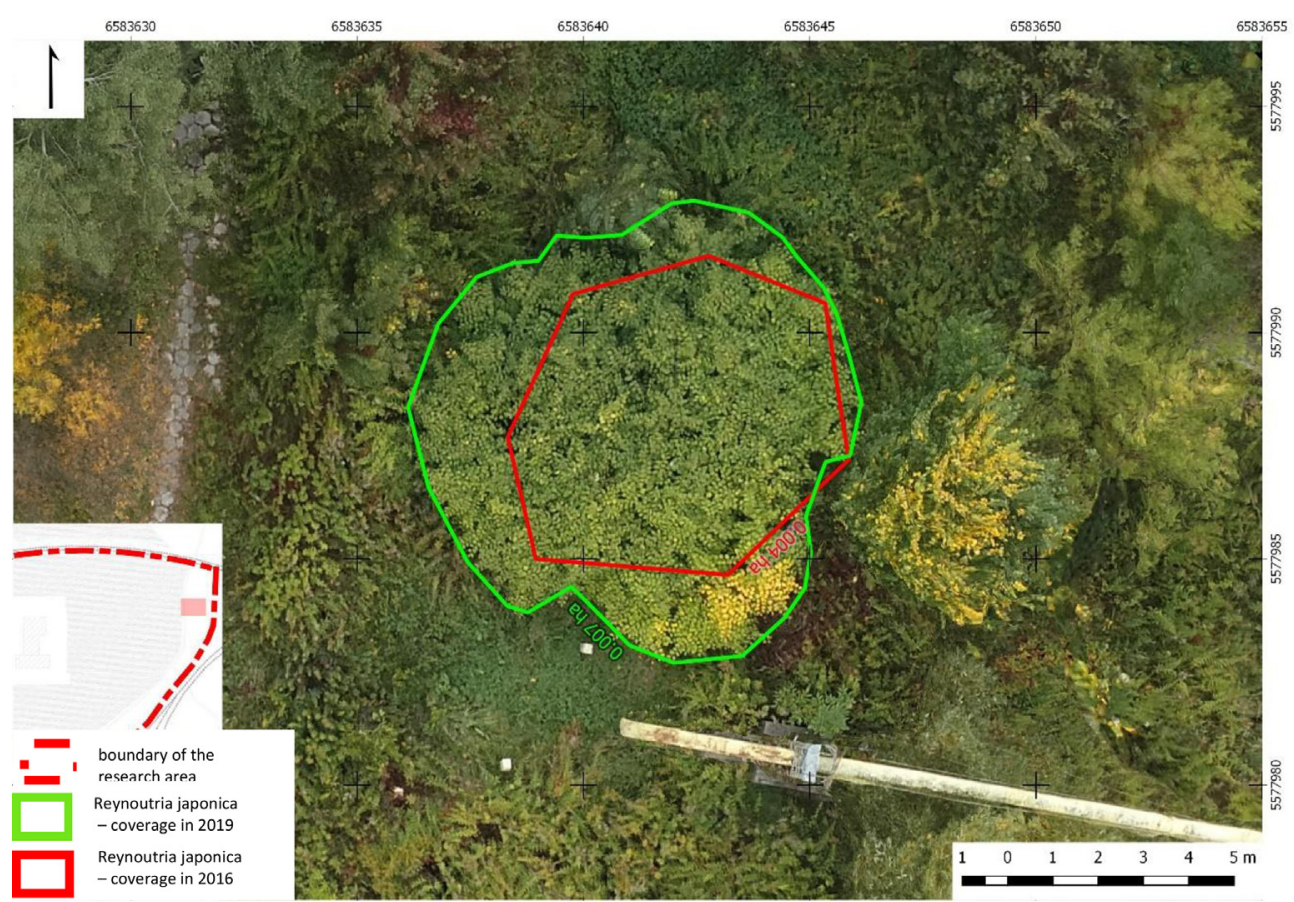

Fig. 8. Fragment of an orthophotomap from 2019. Growth of the Japanese knotweed patch located in the east part of the studied area. Area of the patch in 2016 marked in red. Range of the patch in 2019 marked in green. 
terms of the goldenrod control given its direct adjacency to the railway tracks. The goldenrod in this area is present in the form of significantly stretched and long patches (Figs. 2 and 3). Railway embankments with gentle slopes exposed to solar radiation will always be at risk of goldenrod invasion due to the movement of rolling stock (diaspora dispersion) and the extraordinarily common occurrence of this species in the exact same habitats also outside the focus of this analysis. Spraying and mowing in this part should be repeated much more frequently relative to the rest of the area. It should be noted that railway traffic maintenance services carry out self-seeding plant mowing along the embankments, but the purpose of these efforts is only to maintain smooth and safe railway traffic. Undertaking systemic action aimed at controlling invasive species along railway tracks appears very difficult at the moment.

The Japanese knotweed association occupied an area of 0.281 ha in 2015 . As a result of the maintenance work carried out in 2016, its surface was reduced by 0.027 ha. It underwent dynamic growth in subsequent years. In 2019, the association occupied an area of 0.648 ha, which constituted $3.8 \%$ of the studied location.

A method that guarantees effective knotweed elimination is soil replacement, which would entail the removal of the rhizome-containing soil to a depth of $3 \mathrm{~m}$ and at a distance of $7 \mathrm{~m}$ away from the parent plant, the transport of said soil to a waste disposal ground and its storage at a great depth. In order to effectively eliminate knotweed plants occupying an area of $1 \mathrm{~m}^{2}$, it is necessary to remove over $500 \mathrm{~m}^{3}$ of soil $[5,4,20]$. In the case of the area in question, after factoring in the number and location of individual patches, it would be necessary to transport about 20 thousand $\mathrm{m}^{3}$ of soil. Though the removed volume could be partially replenished with material from the dismantled "Jadwiga" dump, this method would nevertheless be extremely expensive. Factoring in the necessary groundwork, the cost of transportation to the nearest waste disposal ground, and primarily the storage fee, the cost of eliminating the knotweed using this method would amount to about 1.3 million EUR.

Since the entire studied area constitutes post-industrial land, strongly degraded and located away from farmlands, water courses and reservoirs, the knotweed elimination in this case could be accomplished by mowing combined with herbicide spraying.

The best results were observed when the knotweed was sprayed with a mix of herbicides containing three active substances - clopyralid, fluroxypyr and triclopyr. $97 \%$ of the plants were killed eight weeks after spraying, and only $7 \%$ of the plants regrew from subterranean organs five months after the procedure. Such action would need to be repeated at least for the next three years [4].

The first spraying can be performed in May or June, when the plants are about $1 \mathrm{~m}$ high and produce leaves. The second spraying can be carried out in early autumn, during fluorescence [21].

Mowing in the proposed combined method should be performed four to eight times, including always after spraying.

The costs of knotweed elimination using this method amount to about 17.7 thousand EUR/year/ ha. The procedure should be repeated for at least three years, which yields a total cost of about 53.1 thousand EUR.

Box elder $A$. negundo $\mathrm{L}$. had a relatively minor presence in the studied area. The vegetation inventory revealed the existence of 110 specimens of this species, which constituted $2.45 \%$ of the total number of trees. These were specimens with thicknesses ranging from 21 to $69 \mathrm{~cm}$ (at breast height). The vast majority of them could be exempted from the logging fee in 2015 as per the Polish Environmental Protection Law (art. 86 sec. 1 item 7) of 2004 [16]. The box elder logging fee estimated at the time, amounting to nearly 8.4 thousand EUR, concerned multi-stem specimens with total circumferences of over $120 \mathrm{~cm}$. The costs related to the felling,

Table 1. Elimination costs for significant invasive plant species communities located at the "Jadwiga" dump and its vicinity.

\begin{tabular}{|c|c|c|c|}
\hline $\begin{array}{l}\text { Invasive species } \\
\text { /association/community }\end{array}$ & $\begin{array}{l}\text { Occupied area } \\
\text { /number of specimens }\end{array}$ & $\begin{array}{l}\text { Elimination method, number of procedures, } \\
\text { elimination period }\end{array}$ & $\begin{array}{l}\text { Costs [thousands } \\
\text { of EUR] }\end{array}$ \\
\hline Acer negundo L. box elder & 110 specimens & one-time logging (with fees) & 8.8 \\
\hline $\begin{array}{l}\text { Polygonetum cuspidati (Moor 1958) } \\
\text { Th. Müller et Görs } 1969 \text { ex Görs } 1974 \\
\text { Japanese knotweed association }\end{array}$ & 0.648 ha & $\begin{array}{l}\text { Over a year: } 2 x \text { herbicide mixture spraying } \\
\text { combined with } 4 x \text { mowing. } \\
3 \text { subsequent years. }\end{array}$ & 53.1 \\
\hline Robinia pseudoacacia L. false acacia & 1300 specimens & one-time logging (with fees) & 74.5 \\
\hline $\begin{array}{l}\text { Solidago canadensis } \\
\text { Canadian goldenrod community }\end{array}$ & $1.6 \mathrm{ha}$ & $\begin{array}{l}\text { Over a year: } 2 x \text { natural herbicide spraying } \\
\text { combined with } 2 x \text { mowing. } 3 \text { subsequent years. }\end{array}$ & 34.5 \\
\hline Total cost of action & & & 170.9 \\
\hline
\end{tabular}




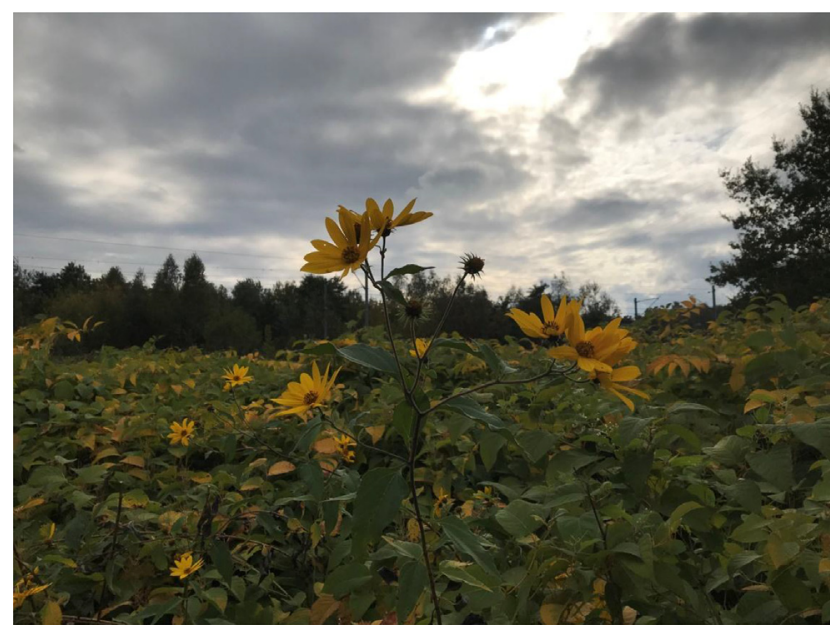

Fig. 9. Jerusalem artichoke Helianthus tuberosus L. accompanying widespread Japanese knotweed patches in the north-eastern part of the studied area.

skidding and fragmentation were estimated at a level of about 440 EUR. It was assumed that the box elder elimination costs would be similar as in 2015, and thus in 2020 they would be at a level of about 8.8 thousand EUR. In the case of variant " 0 ", the box elder would need to be retained.

Elimination costs for significant invasive plant species communities located at the "Jadwiga" dump and its vicinity are presented in Table 1.

Jerusalem artichoke $H$. tuberosus L. in the form of just a few small patches with a total area of $5 \mathrm{~m}^{2}$ accompanied the Japanese knotweed association in the north-eastern part of the studied location (Fig. 9). The artichoke would also need to be subjected to mowing and spraying should the knotweed undergo elimination. The elimination costs in this case would be insignificant.

The remaining invasive species, i.e. New York aster Aster novi-belgii L., annual fleabane E. annuus (L.) and Canadian horseweed C. canadensis (L.), will always occur in this type of land, regardless of the adopted reclamation variant. Particular monitoring should be devoted to climbing plants, i.e. traveller's joy C. vitalba L. and thicket creeper Parthenocisus inserta (A. KERN), which currently have a minor presence in the area, but which may form widespread seam communities in the future that are dangerous to other plants.

\section{Conclusions}

A multi-variant land development concept was prepared for the "Jadwiga" waste dump and its vicinity, constituting a part of the former KWK Paryż mine in Dąbrowa Górnicza, which ultimately provided 5 variants of action. Four of these involved selling the area or making it available to investors, combined with the maximum possible use of the aggregates, coal and wood present there. One of the variants - variant " 0 " (costless) - assumed that the dump and its vicinity would not be altered in order to retain the established post-industrial ecosystem.

The conducted economic analysis of the four different reclamation variants (excluding variant " 0 ") revealed all of them to be cost ineffective. The incurred costs of the work would not be compensated by the income from selling the obtained aggregates, coal and wood and the entire area itself.

The first UAV flights were conducted over the studied location in 2015 with the purpose of assessing the areas of the two significantly widespread formations of invasive species: the Canadian goldenrod S. canadensis community and the Japanese knotweed P. cuspidati (Moor 1958) Th. Müller et Görs 1969 ex Görs 1974 association. The goldenrod surface area measured on the orthophotomaps prepared at the time was 1.218 ha $(10.23 \%$ of the studied location). The Japanese knotweed association occupied 0.281 ha $(2.36 \%$ of the studied location).

The flights and the monitoring of the aforementioned formations were continued in the subsequent years, from 2016 to 2019. Significant growths of the formations were observed. In 2019, the area occupied by the goldenrod was 1.6 ha (which constitutes an increase by $31 \%$ compared to 2015). The knotweed occupied 0.648 ha (increase by $230 \%$ ) in 2019 .

The false acacia $R$. pseudoacacia community present in the area is significant from the perspective of the vegetation and the reclamation efforts. Since a vegetation inventory was taken in 2015 together with an evaluation of the wood that could be obtained, it was possible to determine the fees for removing the false acacia. The costs related to the removal of another invasive species, box elder A. negundo L., were estimated in the same way.

The costs related to the elimination of four invasive plant species by means of methods recommended and described in this article were estimated based on a previously prepared concept, a vegetation inventory and studies employing UAV. This elimination, based on:

- the one-time logging of the box elder A. negundo L.,

- the one-time logging of the false acacia R. pseudoacacia L.,

- the three-year mowing and spraying of the Canadian goldenrod S. canadensis L.,

- and the three-year mowing and spraying of the Japanese knotweed $R$. japonica Houtt., would involve a cost of about 171 thousand EUR. 
The costs of the one-time false acacia and box elder logging were included in the proposed reclamation variants for the entire area (excluding variant " 0 ").

Eliminating the Japanese knotweed association and the Canadian goldenrod community will be an additional cost, estimated at a level of 87.6 thousand EUR. This sum increases the area reclamation cost for the most effective variant "IC" (expenditure of about 490 thousand EUR) by nearly $18 \%$. This provides a new perspective on all the reclamation variants proposed in 2015.

The remaining invasive plant species identified in the studied area should be subjected to monitoring. Apart from continued monitoring, variant " 0 ", which assumes that the dump and its vicinity would remain in an unaltered state, also requires undertaking elimination action, as the area in question is currently a "transit point" that allows invasive plant species to spread into adjacent regions.

\section{Conflicts of interest}

None declared.

\section{Ethical statement}

The author states that the research was conducted according to ethical standards.

\section{Funding body}

None.

\section{References}

[1] Ciepiela B. Najstarsze i ostatnie kopalnie węgla w Zagłębiu Dąbrowskim. [The oldest and last coal mines in the Dabrowa Basin]. Sosnowiec: Stowarzyszenie Autorów Polskich; 2003.

[2] Williams F, Eschen R, Harris A, Djeddour D, Pratt C, Shaw RS, et al. The economic cost of invasive non-native species to the British economy. Wallingford: CABI; 2010. p. 198.

[3] Middleton C. Japanese Knotweed: the invasive plant that eats the value of your home. Newsweek; 2014 (date of acess: 20.01.2021), japanese-knotweed-driving-menmurder.

[4] Tokarska-Guzik B, Fojcik B, Bzdęga K, Urbisz A, Nowak T, Pasierbiński A, et al. Wytyczne dotyczące zwalczania rdestowców na terenie Polski. [Guidelines for knotweed control in Poland]. U.Ś. Katowice; 2015.

[5] Wade M, Child L, Adachi N. Japanese Knotweed - a cultivated coloniser. Biol Sci Rev 1996;8:31-3.

[6] Jones D, Fowler MS, Hocking S, Eastwood D. Please don't mow the Japanese knotweed! NeoBiota 2020;60:19-23.

[7] Kwiatkowska M, Jarosiewicz P, Bukowska B. Glifosat i jego preparaty - toksyczność, narażenie zawodowe i środowiskowe. [Glyphosate and its preparations - toxicity, occupational and environmental exposition]. Medycyna Pracy 2013;64(5):717-29.

[8] Jones D, Bruce G, Fowler MS, et al. Optimising physiochemical control of invasive Japanese knotweed. Biol Invasions 2018;20. 2091-2105.
[9] Olszewski P, Grabowski J, Kelm M. Evaluation of resources and dynamics of plant communities of invasive species in forestland and post-industrial areas. In: 16th International Multidisciplinary Scientific GeoConference SGEM, Vienna; 2016. p. 423-8.

[10] Olszewski P, Grabowski J, Kelm M. Wykorzystanie zdalnie pilotowanych systemów latających do oceny zasobów wielkopowierzchniowych zbiorowisk gatunków inwazyjnych [Using remotely piloted aircraft systems for the evaluation of resources of large-area communities of invasive species], Wiadomości melioracyjne i ląkarskievol. 1. Warszawa: SITWM, Kwartalnik; 2017. p. 16-23.

[11] Rozporządzenie wykonawcze Komisji UE nr 2016/1141 z dnia 13 lipca 2016 r. przyjmującym wykaz inwazyjnych gatunków obcych uznanych za stwarzające zagrożenie dla Unii [Commission Implementing Regulation (EU) 2016/1141 of 13 July 2016 adopting a list of invasive alien species of Union concern pursuant to Regulation (EU) No 1143/2014 of the European Parliament and of the Council].

[12] Rozporządzenie nr 2017/1263 z dnia 12 lipca 2017 r. aktualizującym wykaz inwazyjnych gatunków obcych uznanych za stwarzające zagrożenie dla Unii, ustanowiony w rozporządzeniu wykonawczym Komisji UE nr 1143/2014 [Commission Implementing Regulation (EU) 2017/1263 of 12 July 2017 updating the list of invasive alien species of Union concern established by Implementing Regulation (EU) 2016/1141 pursuant to Regulation (EU) No 1143/2014 of the European Parliament and of the Council].

[13] Rozporządzenie Ministra Środowiska z dnia 9 września 2011 r. w sprawie listy roślin i zwierząt gatunków obcych, które w przypadku uwolnienia do środowiska przyrodniczego moga zagrozić gatunkom rodzimym lub siedliskom przyrodniczym [Regulation of the Minister of the Environment of 9 September 2011 on the list of non-native species of plants and animals, which in the case of release into the environment can threaten native species or natural habitats].

[14] Tokarska-Guzik B, Dajdok Z, Zając M, Zając A, Urbisz A, Danielewicz W, et al. Rośliny obcego pochodzenia w Polsce ze szczególnym uwzględnieniem gatunków inwazyjnych. [Plants of foreign origin in Poland with particular inclusion of invasive species]. Warszawa. 2012.

[15] Węgiel A, Maliński T, Bocianowski J, Rączka G, Sugiero D. [Equations for predicting age of black locust (Robinia pseudoacacia L.) based on the tree circumference]. Sylwan 2017; 161(10):831-41.

[16] Ustawa o ochronie przyrody z dnia 16 kwietnia 2004 art. 84, 85 i 86 wraz z późn. zmianami. [Polish Environmental Protection Law of 16th April 2004, art. 84, 85 and 86, as amended].

[17] Kabuce N, Priede N. NOBANIS - invasive alien species fact sheet - Solidago canadensis. - from: online database of the European network on invasive alien species - NOBANIS. 2010. www.nobanis.org. [Accessed 26 April 2021].

[18] Szépligeti M, Kun R, Bartha S, Bodonczi L, Szentirmai I. Experience gained from the control of giant goldenrod in the Örség National Park. In: Csiszár Á, Korda M, red, editors. Practical experiences in invasive alien plant control. Budapest: Rosalia Handbooks, Duna-Ipoly National Park Directorate; 2015. p. 131-5.

[19] Rajdus T, Švehláková H. Vliv managementu na invazní potenciál zlatobýlu kanadského Solidago canadensis $\mathrm{v}$ CHKO Poodrí. Diplomová práce. [The Effect of Management on Solidago canadensis Invasive Potential in the Poodři PLA]. VŠB, TU - Ostrava; 2018 (date of acess: 20.01.2021), https://dspace.vsb.cz/handle/10084/130117.

[20] Rennocks L. Knotweed control: implications for biodiversity and economic regeneration in Cornwall. Rosewarne: Duchy College; 2007. 2007.

[21] Barták R, Konupková-Kalousová Š, Krupová B. Methods of elimination of invasive knotweed species. (Reynuotria spp.). PROprint, Český Těšín; 2010. 